\title{
Amino Acid Composition of Tightly Bound Exopolymeric Substances Produced by Corrosion-Related Bacteria in Presence of Mild Steel
}

\author{
Mariia Boretska $^{1 * \#, ~ I a r y n a ~ D a t s e n k o 1 \#, ~ O l g a ~ S u s l o v a ~}{ }^{1}$, Olena Pareniuk ${ }^{2 \dagger}$, Olena Moshynets ${ }^{3}$ \\ ${ }^{1}$ General and Soil Microbiology Department, Zabolotny Institute of Microbiology and Virology, National \\ Academy of Sciences of Ukraine, Kiev, Ukraine \\ ${ }^{2}$ Ukrainian Institute of Agricultural Radiology, National University of Life and Environmental Sciences of \\ Ukraine, Kiev, Ukraine \\ ${ }^{3}$ Cell Regulatory Mechanisms Department, Institute of Molecular Biology and Genetics, National Academy of \\ Sciences of Ukraine, Kiev, Ukraine \\ Email: ${ }^{*}$ maria.boretska@gmail.com
}

Received 1 July 2014; revised 2 August 2014; accepted 1 September 2014

Copyright (C) 2014 by authors and Scientific Research Publishing Inc.

This work is licensed under the Creative Commons Attribution International License (CC BY).

http://creativecommons.org/licenses/by/4.0/

(c) (i) Open Access

\begin{abstract}
The composition of tightly bound exopolymeric substances (EPS) obtained from biofilm and planktonic cell subpopulations of Stenotrophomonas maltophilia 5426 UKM was analyzed to study an impact of mild steel presence in the cultivation medium. The overall protein production was found to increase in the presence of a steel coupon. Some amino acids such as lysine, valine, iso-leucine, tyrosine and phenylalanine were found to be secreted in higher amounts in the presence of mild steel, while its absence leads to an increase of arginine, asparagine, serine, glutamine, proline, glycine, cysteine, leucine, methionine production levels. Biofilm cells EPS contained more arginine, glycine, cysteine, valine, methionine and leucine, comparing to EPS of planktonic cells. The changes of tightly bound EPS aggregation around the cells induced in the presence of steel coupons were revealed by transmission electron microscopy. The results suggested the transition of $S$. maltophilia 5426 UKM cells from planktonic to biofilm lifestyle to be a complex process involving more than a single step.
\end{abstract}

\section{Keywords}

EPS, Stenotrophomonas maltophilia, Biofilm, Amino Acid Composition, Ion Exchange

\footnotetext{
*Corresponding author.

\#Authors contributed equally to this research.

${ }^{\dagger}$ The current working place is Institute of Environmental Radioactivity, Fukushima University, Fukushima City, Japan.
} 


\section{Chromatography, Mild Steel, Biocorrosion}

\section{Introduction}

In industry susceptibility of metals to corrosion depends on a number of environmental factors. Microbial activity, although underestimated in the past, is now considered to be responsible for many cases of corrosion failures with estimated economic losses up to \$10 million per event [1]. The deterioration of metal due to microbial activity is termed biocorrosion or microbially influenced corrosion (MIC). Owing to its economic and environmental importance, MIC has been the subject of extensive studies for the past five decades and several models have been proposed to explain mechanisms governing biocorrosion [2]. The growth of microbial biofilms affects the chemistry of near-surface environment either directly, when a specific metabolic reaction or product of the microbial metabolism acts as a reactant in electrochemical corrosion processes, or indirectly, when the biofilm or its matrix modifies physico-chemical environment where these reactions take place [3]. The main types of bacteria associated with metals in terrestrial and aquatic habitats are sulfate reducing bacteria, sulfur-oxidizing bacteria, iron oxidizing/reducing bacteria, manganese-oxidizing bacteria, and bacteria secreting organic acids and slime. However, microbial tendency to build complex consortia should be also taken into account [4]. Apart from metabolic cooperation, interspecies interactions within biofilm between primary and secondary colonizers are considered to be important, resulting in cell co-aggregation and, thus, stronger biofilm formation. These interactions were well described for dental plague, as well as for bioleaching biofilms, and they are supposed to exist in numerous natural environments [5] [6]. Thus, some bacteria may contribute to the corrosion processes carried out by consortia without exhibiting much effect on metal substrata by supporting the growth of the key players in MIC. A good example of bacterial cooperation within corrosion-relevant community is the relation between the heterotrophic bacteria Stenotrophomonas maltophilia and bacteria of the sulfur cycle. These organisms were found to coexist in biofilms formed on corroded metal surfaces, exhibiting synergistic effect while making an impact on the colonized surface [7].

An integral part of any biofilm is its self-produced matrix. It consists of different kinds of biopolymers, including proteins, polysaccharides, nucleic acids and lipids, known as extracellular polymeric substances (EPS) [8]. EPS production facilitates biofilm formation and maturation enabling surface conditioning, cell adhesion, cohesion within microcolonies and playing a protective role [9]. However, its contribution to MIC is still under discussion. One of the properties of EPS, which draws attention of the investigators with regard to MIC, is its capacity to bind metal ions [10]-[12]. Metal binding by EPS occurs due to the interactions between their functional groups such as carboxyl, phosphoric, sulfhydryl, amine or hydroxyl groups and cations [13]. EPS normally act as polyanions under natural conditions by formation of salt bridges with carboxyl groups of acidic polymers (polysaccharides containing uronic acids) or by forming weak electrostatic bonds with hydroxyl groups on polymers containing neutral carbohydrates. In addition, there may also be cationic binding by positively charged polymers or coordination with hydroxyl groups. Although bacterial EPS have been shown to exhibit selectivity in complexing metal ions, in most cases the type of macromolecules playing a key role in metal binding has not been determined [14]. Some investigators claim that binding properties of EPS can determine its contribution to MIC. Beech and colleagues compared EPS obtained from two strains of sulfate-reducing bacteria (SRB) belonging to the same genus and demonstrated that EPS with higher ion-binding capacity was produced by the more corrosive strain [4]. Later a mechanism was suggested involving $\mathrm{Fe}^{3+}$-EPS complexes into electron transfer to explain the observed corrosion acceleration in an oxygenated biofilm [2]. However, there are reports on corrosion inhibiting effects of EPS. Chelating capacity of EPS was suggested to be involved in the complexation of medium compounds with subsequent formation of a protective film [15]. Mitigation strategies based on antifouling and corrosion inhibiting properties of EPS produced by some bacterial species were discussed [16].

Composition of EPS depends on many factors and may change depending on conditions. Regarding the importance of its interactions with metal ions during the biofilm formation by corrosion-related microorganisms, alteration of EPS production by sulfate reducing bacteria in presence of mild steel surface has been investigated. Chromatography tools applied proved to be efficient in revealing changes of the monosaccharide composition [17]. However, considering the growing recognition of the importance of proteinaceous compounds for the biofilm formation, amino acid composition changes were chosen as the focus of the study. S. maltophilia 5786 
UKM was selected as a strain commonly associated with corrosive sulfur-oxidizing bacteria, which may contribute to the general corrosiveness of the consortia by massive EPS production stabilizing the structure of biofilm and binding metal ions [18].

The investigations on the role of non-corrosive members of corrosion-relevant consortia undertaken in this study are suggested to be a new approach able to deliver deeper understanding of the processes of MIC.

\section{Material and Methods}

\subsection{Microorganisms and Cultivation}

Stenotrophomonas maltophilia strain 5786 UKM (Ukrainian Collection of Microorganisms) was cultivated on DSM 36 medium $\left(\left(\mathrm{NH}_{4}\right)_{2} \mathrm{SO}_{4} 0.10\right.$ g, $\mathrm{K}_{2} \mathrm{HPO}_{4} 4.00 \mathrm{~g}, \mathrm{KH}_{2} \mathrm{PO}_{4} 4.00 \mathrm{~g}, \mathrm{MgSO}_{4} \times 7 \mathrm{H}_{2} \mathrm{O} 0.10 \mathrm{~g}, \mathrm{CaCl}_{2} 0.10 \mathrm{~g}$, $\mathrm{FeCl}_{3} \times 6 \mathrm{H}_{2} \mathrm{O} 0.02 \mathrm{~g}, \mathrm{MnSO}_{4} \times \mathrm{H}_{2} \mathrm{O} 0.02 \mathrm{~g}, \mathrm{Na}_{2} \mathrm{~S}_{2} \mathrm{O}_{3} \times 5 \mathrm{H}_{2} \mathrm{O} 10.00 \mathrm{~g}$, distilled water $1000.00 \mathrm{~mL}$ ) with addition of $2 \%(58.4 \mathrm{mM})$ maltose sterilized separately. Inoculum was introduced into $40 \mathrm{ml}$ of medium with initial $\mathrm{pH} 7.2$ to the cell number of $1 \times 10^{8}$ cells/ml. Bacteria were grown at the temperature of $28^{\circ} \mathrm{C}$ under agitation to provide aeration (140 rpm). Cell number was determined after 2, 4, 7 and 11 days of cultivation. Cell amounts were determined using a counting chamber with a phase-contrast microscope (MT 4000, MEIJI Tech, Japan) at $400 \times$ magnification. Preliminary evaluation of total extracellular protein production by planktonic cells was performed in EPS samples obtained as described below using BSA as standard [19]. Spectrophotometry was performed using NanoDrop 1000 (Thermo Fisher Scientific, USA).

\subsection{Metal and Glass Specimen Preparation}

For biofilm formation experiments mild steel coupons and glass slides were used. Coupons of mild steel S235J2G3 with the size $20 \times 40 \times 1 \mathrm{~mm}$ were treated as described, with $0.6 \mathrm{M} \mathrm{HCl}$ used for pickling prior to inoculation [20]. Glass slides $(10 \times 40 \times 1 \mathrm{~mm})$ were degreased with sodium dodecyl sulfate, washed with deionized water and autoclaved at $121^{\circ} \mathrm{C}$ under 1.5 bar [18].

\subsection{Microscopy Analyses}

Transmission electron microscopy (TEM) was applied to visualize planktonic cells and their capsules. Samples were prepared by the modified floating drop method [21].

After 2, 4, 7 and 11 days of cultivation $50 \mu \mathrm{L}$ of culture were taken and the drop was placed on Parafilm ${ }^{\circledR}$ sheets. Formvar ${ }^{\circledR}$ coated copper grid was put on the drop. Cells were allowed to adhere for $10 \mathrm{~min}$; afterwards the grids were air-dried. Samples were observed using a TEM (Jeol 1400, Japan) at an accelerating voltage of 80 $\mathrm{kV}$. For each sample 20 images were acquired.

Confocal laser scanning microscopy (CLSM) was used to visualize the cells and the biofilm on the mild steel and glass surfaces. The coupons and slides were retrieved from the culture medium and rinsed with the medium in order to prevent the attachment of planktonic cells. Nucleic acids of biofilm cells were stained with $0.01 \%$ w/v DAPI (Sigma) containing 2\% v/v formaldehyde for $10 \mathrm{~min}$. Staining was performed avoiding direct sunlight. Afterwards the samples were rinsed with particle-free water, air-dried and after applying an antifading agent CitiFluorTM AF2, observed using a laser scanning module (LSM 510 Carl Zeiss, Jena) coupled to an inverted Axiovert 100 MBP microscope (Zeiss). For each sample 20 images were acquired. All images were obtained with the plan-apochromatic $100 \times 0.79$ oil DIC objective. The microscope was operated with the software LSM 510 Release 3.2 (Carl Zeiss, Jena) [22].

\subsection{EPS Extraction}

After 2, 4, 7 and 11 days of $S$. maltophilia 5786 UKM cultivation culture medium was centrifuged at $7000 \mathrm{rpm}$ for $10 \mathrm{~min}$ and cell pellets were resuspended in $20 \mathrm{~mL}$ of PBS buffer $\left(2 \mathrm{mM} \mathrm{Na}_{3} \mathrm{PO}_{4}, 4 \mathrm{mM} \mathrm{NaH}_{2} \mathrm{PO}_{4}, 9 \mathrm{mM}\right.$ $\mathrm{NaCl}, 1 \mathrm{mM} \mathrm{KCl}$; $\mathrm{pH}$ 7). Then the equivalent volume of cation exchange resin (DOWEX ${ }^{\mathrm{TM}}$ Marathon C, Sigma) previously treated with PBS buffer for $1 \mathrm{~h}$ was added and extraction was performed for $4 \mathrm{~h}$ at $4^{\circ} \mathrm{C}$ with stirring at $100 \mathrm{rpm}$. Afterwards the aqueous phase was filtered through a glass filter funnel (Simax) and the filter was washed with $10 \mathrm{~mL}$ of PBS buffer to obtain EPS extract trapped within DOWEX ${ }^{\mathrm{TM}}$ beads. This EPS containing extract was centrifuged at $6000 \mathrm{rpm}$ for $5 \mathrm{~min}$, filtered through a $0.2 \mu \mathrm{m}$ pore size membrane filter and dialyzed 
overnight against $\mathrm{ddH}_{2} \mathrm{O}$ using a $3.5 \mathrm{kDa}$ cutoff membrane tube (Sigma).

In order to obtain EPS from biofilm cells these were detached by ultrasound treatment of coupons in $14.5 \mathrm{mM}$ $\mathrm{NaCl}$ solution by a non-destructive regime $(22 \mathrm{kHz})$ as described [20].

The resulting cell suspension was treated as described for the planktonic cells. EPS extraction was performed in triplicates. All samples were freeze-dried and then dissolved in deionized water. EPS samples were used for the protein determination and amino acid composition analyses.

\subsection{Amino Acid Composition Analyses}

For amino acid composition analyses EPS were resuspended in $2 \mathrm{~mL}$ of deionized water. Proteolysis and ion exchange chromatography (IEC) were performed with an Amino Acid Analyzer T, Czech Republic, as described [23].

\section{Results}

Growth of S. maltophilia 5786 UKM in the presence of a mild steel coupon was monitored by cell counting during the cultivation period of 11 days. Additionally, protein accumulation in EPS was measured.

The results suggest that a mild steel coupon introduction had little effect on the growth curve of S. maltophilia 5786 UKM culture (Figure 1). The culture reached the maximal cell number at the $7^{\text {th }}$ day of cultivation independently of the presence of steel. The coupon-free culture reached the cell number of $2.5 \times 10^{8}$ cells $\cdot \mathrm{mL}^{-1}$, which was insignificantly lower than in the presence of mild steel $\left(3.1 \times 10^{8}\right.$ cells $\left.\cdot \mathrm{mL}^{-1}\right)$. The presence of mild steel caused an increase in extracellular protein production. The highest total extracellular protein concentration, around $1.7 \mu \mathrm{g} \cdot \mathrm{mL}^{-1}$, was found in EPS isolated from 7 days old S. maltophilia 5786 UKM culture grown in the presence of a mild steel coupon (Figure 1).

Considering possible morphology changes of the planktonic cells of S. maltophilia 5786 UKM, in presence of mild steel microscopic observation was undertaken on each step of cultivation. Morphological alteration of the structure of planktonic cell capsule on the $7^{\text {th }}$ day of cultivation under the influence of carbon steel presence was visualized by TEM (Figure 2). The thickness of a capsule was shown to increase in average to $0.3 \mu \mathrm{m}$ comparing to the conditions without steel.

CLSM observations of the cells of S. maltophilia 5786 UKM performed after 2, 4, 7 and 11 days cultivation allowed tracking the process of biofilm formation (Figure 3). Although the cell attachment was observed on both glass and mild steel surfaces, the number of cells adhered to the glass surface remained comparatively low.

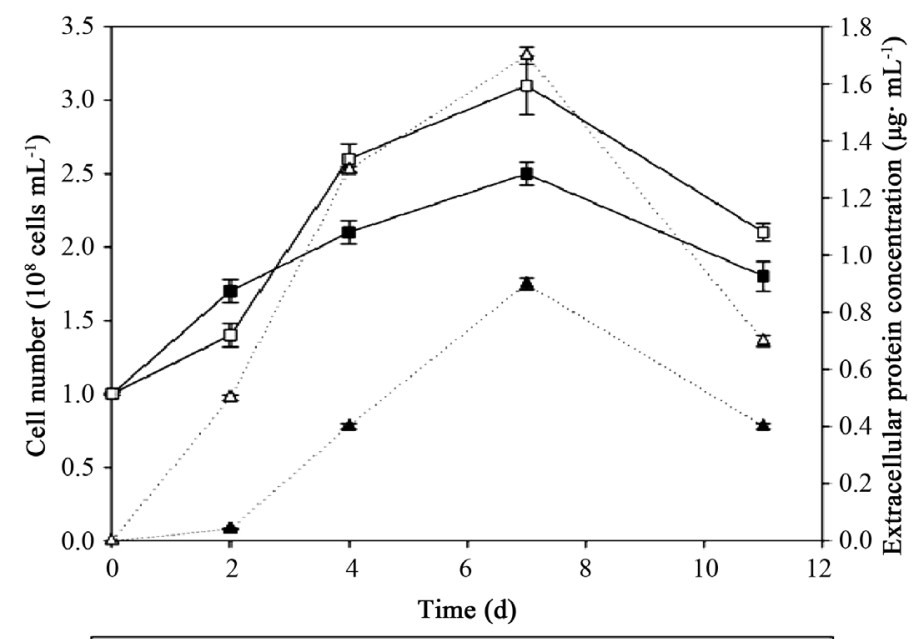

$$
\begin{aligned}
& - \text { Growth in coupon-free medium } \\
& - \text { - Growth in the presence of mild steel } \\
& \cdots . \text { Total extracellular protein production in coupon-free medium } \\
& \cdots \cdots \text { Total extracellular protein production in the presence of mild steel }
\end{aligned}
$$

Figure 1. Growth of Stenotrophomonas maltophilia 5426 UKM and its production of the extracellular proteins in the presence of mild steel monitored during 11 days. Error bars represent standard deviation. 


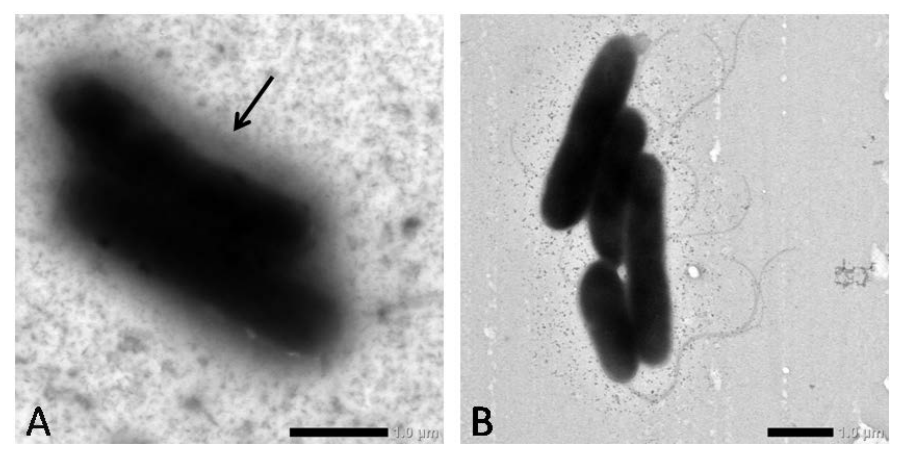

Figure 2. TEM micrographs of Stenotrophomonas maltophilia 5426 UKM planktonic cells on the $7^{\text {th }}$ day of cultivation. (A) Bacteria grown in presence of mild steel coupon; (B) Bacteria grown in steelfree medium. Changes in the capsule thickness are visualized.
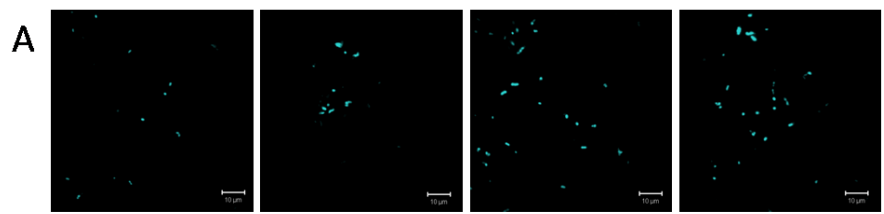

B
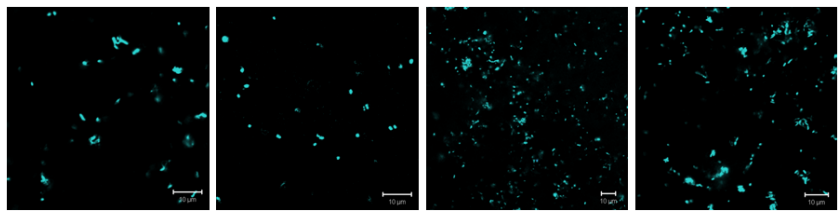

$2 \mathrm{~d}$

$4 d$

$7 \mathrm{~d}$

$11 \mathrm{~d}$

Figure 3. CLSM micrographs of Stenotrophomonas maltophilia 5426 UKM sessile populations on the glass slide (A) and mild steel coupon (B). The attachment was observed on the 2, 4, 7 and $11 \mathrm{~d}$ of cultivation. Bar corresponds to $10 \mu \mathrm{m}$.

Biofilms on the mild steel surface seemed to develop dynamically with microcolonies being clearly distinguishable already after 2 days of growth. By the end of the experiment a well-developed multilayer biofilm was formed on the mild steel surface, suggesting that this is a favorable lifestyle for S. maltophilia 5786 UKM.

The amino acid composition of EPS produced by biofilms and planktonic cells of S. maltophilia 5786 UKM after 2, 4, 7 and 11 days of cultivation was shown to differ qualitatively. IEC revealed the presence of 17 amino acids with the concentrations changing depending on the growth mode, a mild steel coupon presence or the age of the culture subjected to EPS extraction. In all samples glutamic acid was predominant.

Considering that the highest amount of total protein was found in EPS of 7 days old culture, a special attention was paid to the amino acid composition of the respective EPS sample (Figure 4). Production of the proteinacous EPS by the planktonic cells clearly depended on the introduction of mild steel coupon into the culture medium (Figure 1). When the coupon was present, lysine, valine, isoleucine, tyrosine, phenylalanine were found enhanced, while the increased amount of arginine, glutamine, proline, glycine, cysteine was found in EPS obtained from the metal-free culture.

EPS from the biofilm cells also exhibited a number of peculiarities. Arginine, glycine, cysteine, valine, methionine, leucine content increased comparing to the EPS produced by planktonic cells in the presence of mild steel.

\section{Discussion}

In spite of the growing interest of research biocorrosion still remains a hard-to-predict phenomenon affecting oil and gas fields, constructing industries etc. One of the main complications to face when dealing with biocorrosion is a strong dependence of bacterial activity on the unsteady environmental factors such as humidity, $\mathrm{pH}$, 


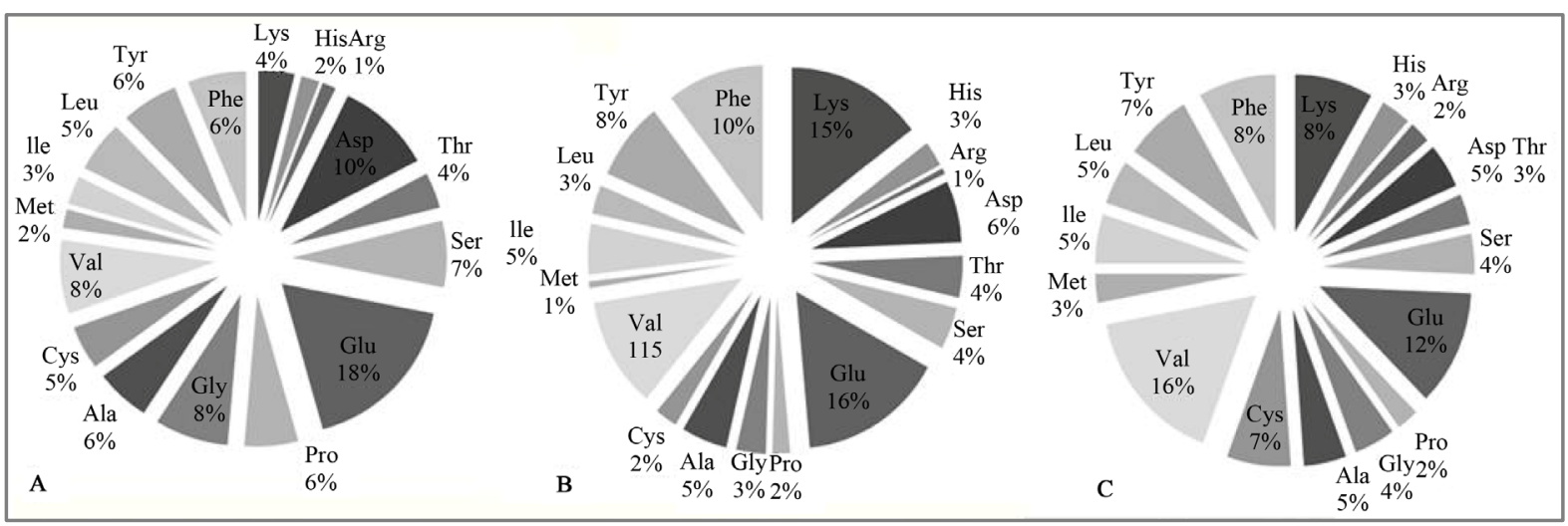

Figure 4. Amino acid composition of tightly bound EPS of planktonic cells in steel-free medium (A), planktonic cells in presence of the mild steel (B), biofilm cells (C) as studied by IEC.

aeration, presence of certain compounds or availability of nutrients or essential microelements. Obviously, such an important factor as a presence of growth substratum may have a strong impact on the physiological status of a microbial population. EPS production, specifically, has been shown to be adaptable depending on the surface available for colonization [17] [24]. Current investigation was aimed to find out how the availability of the mild steel surface may influence growth and activity of S. maltophila 5786 UKM, commonly associated with corrosion relevant sulfur-oxidizing bacteria [18].

Growth monitoring of S. maltophila 5786 UKM showed that no significant change was induced by mild steel coupon introduction into medium. Microscopy studies showed that biofilm was developing on both glass and mild steel surfaces. Attachment to glass previously reported for S. maltophila as well as the possibility to colonize other inert surfaces is believed to be a result of the cell positive surface charge, not so wide-spread among the other Gram-negative bacteria. It helps bacteria to overcome repulsive electrostatic forces preventing bacterial adhesion to the negatively charged surfaces [25]. However, CLSM observation showed clearly that mild steel surface was colonized more intensively, in spite of the positive charge which it should have acquired because of the oxidation processes occurring under aerobic conditions. This fact coincides with the idea of bacterial adhesion being a very complex process.

Among the theories attempting to predict cell adhesive behavior, the most comprehensive one is the extended DLVO theory, considering a number of interactions such as van der Waals, Coulomb, electrostatic, hydrophobic/hydrophilic and osmotic ones. However, it still fails to explain some cases of bacterial adhesion [26]. The main reason for actual adhesion process deviations from models is a variety of structures associated with the cell surface which mediate its interaction with the substratum. Tightly bound EPS as one of the most interesting microbial factors of cell-surface interaction was in the focus of the present study. These compounds draw attention because their production is known to be influenced by environmental conditions, and this kind of environmentally induced flexibility together with the ability to remain in close proximity to a cell make tightly bound EPS an important determinant of the bacterial adhesive properties [27]. TEM observations provide a good evidence of conditions-related EPS production changes, revealed by a thickness increase of the EPS capsula. Considering that polysaccharides often play a leading role in EPS, and having in mind the negative charge of the most of them, a suggestion can be made that in case of S. maltophila 5786 UKM increased EPS production in the presence of mild steel might be induced in order to facilitate adhesion and further efficient biofilm formation on the positively charged surface of the coupon. An increase in the protein production observed after the introduction of the steel coupons the medium might be also related to involvement of the proteinaceous fraction of EPS in the adhesion processes. However, this suggestion should be verified by additional experiments. Application of IEC for the studies of the proteinacous part of tightly bound EPS isolated from S. maltophila 5786 UKM helped to reveal significant differences between amino acid profiles obtained from planktonic cells in the presence or absence of a mild steel coupon, as well as between the profiles of planktonic cells grown with coupon and biofilm formed on this coupon. Noteworthy, peptides and proteins of EPS are known to be important for many aspects of the biofilm development, from the formation of the conditioning layer over EPS anchored enzymes to cohesion of cells within microcolonies and surface-associated migration [28]. Differences in amino acid ratios are 
not the only changes in EPS composition induced by the switch to the biofilm growth mode. A similar effect was described earlier for monosaccharide and fatty acid profiles of S. maltophilia EPS [18]. The combination of these data gives an idea of the importance of the substratum presence for the metabolism regulation of this bacterium.

\section{References}

[1] Maxwell, S., Devine, C. and Rooney, F. (2004) Monitoring and Control of Bacterial Biofilms in Oilfield Water Handling Systems. CORROSION 2004, New Orleans, 28 March-1 April 2004, Document IDNACE-04752.

[2] Beech, I.B. and Sunner, J. (2004) Biocorrosion: Towards Understanding Interactions between Biofilms and Metals. Current Opinion in Biotechnology, 15, 181-186. http://dx.doi.org/10.1016/j.copbio.2004.05.001

[3] Hamilton, W.A. (2003) Microbially Influenced Corrosion as a Model System for the Study of Metal Microbe Interactions: A Unifying Electron Transfer Hypothesis. Biofouling, 19, 65-76. http://dx.doi.org/10.1080/0892701021000041078

[4] Beech, I.B. and Gaylarde, C.C. (1999) Recent Advances in the Study of Biocorrosion: An Overview. Revista de Microbiologia, 30, 117-190. http://dx.doi.org/10.1590/S0001-37141999000300001

[5] Moons, P., Michiels, C.W. and Aertsen, A. (2009) Bacterial Interactions in Biofilms. Criticals Reviews in Microbiology, 35, 157-168. http://dx.doi.org/10.1080/10408410902809431

[6] Florian, B., Noël, N., Thyssen, C., Felschau, I. and Sand, W. (2011) Some Quantitative Data on Bacterial Attachment to Pyrite. Minerals Engineering, 24, 1132-1138. http://dx.doi.org/10.1016/j.mineng.2011.03.008

[7] Borets'ka, M.O. and Kozlova I.P. (2010) Biofilm on a Metal Surface as a Factor of Microbial Corrosion (ukr). Mikrobiologichny Zurnal, 72, 57-65.

[8] Flemming, H.C. and Wingender, J. (2010) The Biofilm Matrix. Nature Review Microbiology, 8, 623-633.

[9] Dunne, W.M. (2002) Bacterial Adhesion: Seen Any Good Biofilms Lately? Clinical Microbiology Reviews, 15, 155166. http://dx.doi.org/10.1128/CMR.15.2.155-166.2002

[10] Sand, W. and Gehrke, T. (2006) Extracellular Polymeric Substances Mediate Bioleaching/Biocorrosion via Interfacial Processes Involving Iron (III) Ions and Acidophilic Bacteria. Research in Microbiology, 157, 49-56. http://dx.doi.org/10.1016/j.resmic.2005.07.012

[11] Ha, J., Gélabert, A., Spormann, A.M. and Brown, G. (2010) Role of Extracellular Polymeric Substances in Metal Ion Complexation on Shewanella oneidensis: Batch Uptake, Thermodynamic Modeling, ATR-FTIR, and EXAFS Study. Geochimica et Cosmochimica Acta, 74, 1-15. http://dx.doi.org/10.1016/j.gca.2009.06.031

[12] Comte, S., Guibaud, G. and Baudu, M. (2006) Biosorption Properties of Extracellular Polymeric Substances (EPS) Resulting from Activated Sludge According to Their Type: Soluble or Bound. Process Biochemistry, 41, 815-823. http://dx.doi.org/10.1016/j.procbio.2005.10.014

[13] Liu, H. and Fang, H.H.P. (2002) Characterization of Electrostatic Binding Sites of Extracellular Polymers by Linear Programming Analysis of Titration Data. Biotechnology and Bioengineering, 80, 806-811. http://dx.doi.org/10.1002/bit.10432

[14] Pal, A. and Paul, A.K. (2008) Microbial Extracellular Polymeric Substances: Central Elements in Heavy Metal Bioremediation. Indian Journal in Microbiology, 48, 49-64. http://dx.doi.org/10.1007/s12088-008-0006-5

[15] Chongdar, S., Gunasekaran, G. and Kumar, P. (2005) Corrosion Inhibition of Mild Steel by Aerobic Biofilm. Electrochimica Acta, 50, 4655-4665. http://dx.doi.org/10.1016/j.electacta.2005.02.017

[16] Stadler, R., Fuerbeth, W., Harneit, K., Grooters, M., Woellbrink, M. and Sand, W. (2008) First Evaluation of the Applicability of Microbial Extracellular Polymeric Substances for Corrosion Protection of Metal Substrates. Electrochimica Acta, 54, 91-99. http://dx.doi.org/10.1016/j.electacta.2008.04.082

[17] Zinkevich, V., Bogdarina, I., Kang, H., Hill, M.A.W., Tapper, R. and Beech, I.B. (1996) Characterisation of Exopolymers Produced by Different Isolates of Marine Sulphate-Reducing Bacteria. International Biodeterioration and Biodegradation, 37, 163-172. http://dx.doi.org/10.1016/S0964-8305(96)00025-X

[18] Borets'ka, M.O. and Kozlova, I.P. (2007) Effect of the Biofilm Biopolymers on the Microbial Corrosion Rate of the Low-Carbon Steel. Mikrobiologichny Zurnal, 69, 40-44.

[19] Bradford, M.M. (1976) A Rapid and Sensitive Method for the Quantitation of Microgram Quantities of Protein Utilizing the Principle of Protein-Dye Binding. Analytical Biochemistry, 72, 248-254. http://dx.doi.org/10.1016/0003-2697(76)90527-3

[20] Asaulenko, L.H., Purish, L.M. and Kozlova, I.P. (2004) Stages of Biofilm Formation by Sulfate-Reducing Bacteria (ukr). Mikrobiolohichnyı zhurnal, 66, 72-79. 
[21] Burghardt, R.C. and Droleskey, R. (2005). Transmission Electron Microscopy. Current Protocols in Microbiology, John Wiley \& Sons, Inc., Hoboken.

[22] Bellenberg , S., Leon-Morales, C.F., Sand, W. and Vera, M. (2012) Visualization of Capsular Polysaccharide Induction in Acidithiobacillus ferrooxidans. Hydrometallurgy, 129-130, 82-89. http://dx.doi.org/10.1016/j.hydromet.2012.09.002

[23] Lošák, T., Hlušek, J., Filipčík, R., Pospíšilová, L., Maňásek, J., Prokeš, K., Buňka, F., Kráčmar, S., Martensson, A. and Orosz, F. (2010) Effect of Nitrogen Fertilization on Metabolisms of Essential and Non-Essential Amino Acids in FieldGrown Grain Maize (Zea mays L.). Plant Soil Environmental, 56, 574-579.

[24] Gehrke, T., Hallmann, R., Kinzler, K. and Sand, W. (2001) The EPS of Acidithiobacillus ferrooxidans-A Model for Structure-Function Relationships of Attached Bacteria and Their Physiology. Water Science and Technology, 43, 159167.

[25] Jucker, B.A., Harms, H. and Zehnder, A.J. (1996) Adhesion of the Positively Charged Bacterium Stenotrophomonas (Xanthomonas) Maltophilia 70401 to Glass and Teflon. Journal of Bacteriology, 178, 5472-5479.

[26] Hori, K. and Matsumoto, S. (2010) Bacterial Adhesion: From Mechanism to Control. Biochemical Engineering Journal, 48, 424-434. http://dx.doi.org/10.1016/j.bej.2009.11.014

[27] Rice, J.F., Fowler, R.F., Arrage, A.A., White, D.C. and Sayler, G.S. (1995) Effects of External Stimuli on Environmental Bacterial Strains Harboring analgD-lux Bioluminescent Reporter Plasmid for the Study of Corrosive Biofilms. Journal of Industrial Microbiology, 15, 318-328. http://dx.doi.org/10.1007/BF01569986

[28] Karatan, E. and Watnick, P. (2009) Signals, Regulatory Networks, and Materials That Build and Break Bacterial Biofilms. Microbiology and Molecular Biology Reviews, 73, 310-347. http://dx.doi.org/10.1128/MMBR.00041-08 
Scientific Research Publishing (SCIRP) is one of the largest Open Access journal publishers. It is currently publishing more than 200 open access, online, peer-reviewed journals covering a wide range of academic disciplines. SCIRP serves the worldwide academic communities and contributes to the progress and application of science with its publication.

Other selected journals from SCIRP are listed as below. Submit your manuscript to us via either submit@scirp.org or Online Submission Portal.
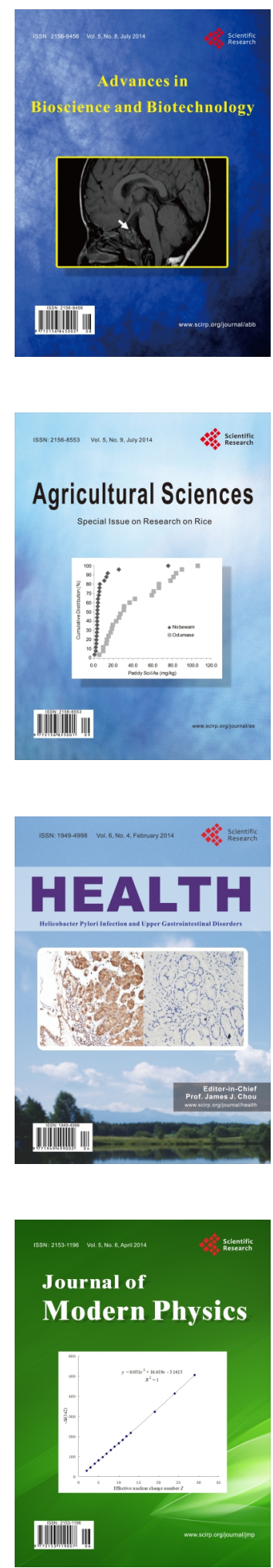
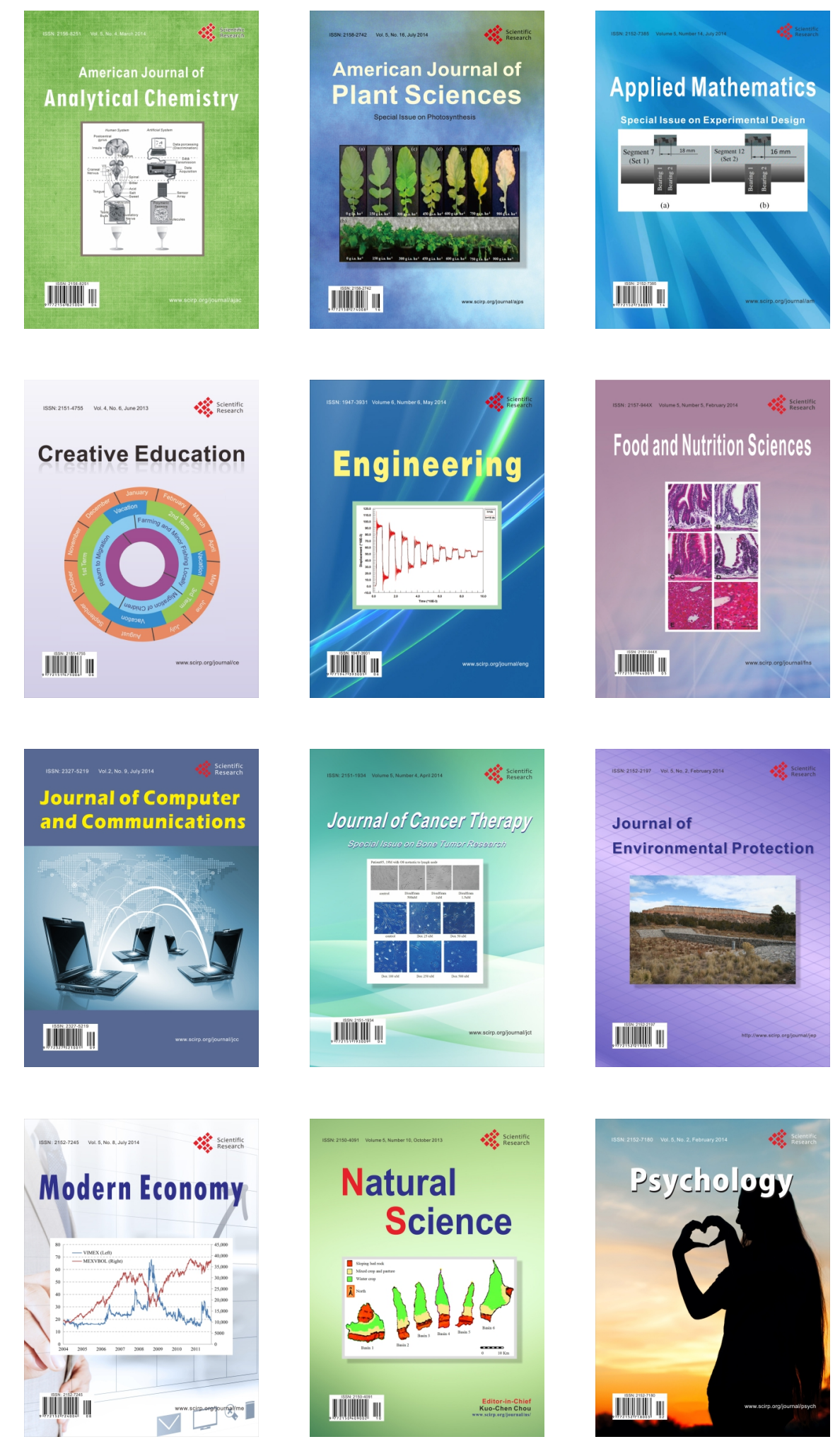